\title{
Pengukuran Beban Kerja, Motivasi Kerja dan Kompensasi Serta Pengaruhnya Terhadap Kinerja Karyawan
}

\author{
Wibawa Prasetya ${ }^{1}$ dan Veronica Gisela ${ }^{2}$ \\ Fakultas Teknik, Jurusan Teknik Industri, Universitas Katolik Indonesia Atma Jaya, \\ Tangerang, Indonesia
}

\begin{abstract}
ABSTRAK
Saat ini perkembangan industri semakin pesat sehingga perusahaan harus memiliki keunggulan yang lebih baik dibandingkan dengan perusahaan lainnya. Penelitian ini bertujuan untuk mengetahui pengaruh variabel kompensasi, beban kerja, dan motivasi kerja terhadap kinerja karyawan. Pengukuran beban kerja mental digunakan metode NASA-TLX sedangkan pengukuran tingkat motivasi kerja digunakan metode JDS. Pengolahan data menggunakan metode Structural Equation Modelling (SEM). Hasil dari penelitian ini adalah tingkat beban kerja mental karyawan dan motivasi kerja yang tinggi. Terdapat 4 hipotesis yang berpengaruh yaitu kompensasi dan beban kerja berpengaruh secara posistif terhadap motivasi kerja, kompensasi dan motivasi kerja berpengaruh positif terhadap kinerja karyawan. Berdasarkan hasil hipotesis yang telah diuji maka perusahaan perlu untuk meningkatkan kinerja karyawan sesuai dengan implikasi manajerial yang diusulkan.
\end{abstract}

Kata kunci: Beban Kerja Mental; NASA-TLX; Motivasi Kerja; JDS; SEM

\begin{abstract}
Currently, the development of the industry is increasing rapidly so the company should have a better advantage compared with other companies. This study aims to determine the effect of variable compensation, workload, and work motivation on employee performance. Measurement of mental workload is measured by using NASA-TLX method while the measurement of work motivation level is measured by using JDS method. Data processing uses Structural Equation Modeling (SEM) method. The results of this study is the insight upon level of mental workload of employees and high work motivation. There are 4 influencing hypotheses which are the compensation and work load positive influence on work motivation, and then compensation and work motivation have a positive effect on employee performance. Based on the results of hypotheses that have been tested then companies need to improve employee performance in accordance with the proposed managerial implications.
\end{abstract}

Keywords: Mental Workload; NASA-TLX; Work Motivation; JDS; SEM

\section{PENDAHULUAN}

Perkembangan industri sekarang ini menjadi semakin pesat karena adanya teknologi dan inovasi baru sehingga melahirkan banyak perusahaan baik di bidang jasa maupun manufaktur. Setiap perusahaan pastilah menghasilkan suatu produk di mana produk yang dihasilkan tersebut dapat sejenis dan diproduksi tidak hanya dari satu perusahaan saja. Tentu saja hal ini membuat banyak perusahaan bersaing agar dapat memiliki keunggulan dibandingkan dengan perusahaan sejenis lainnya. Porter (1986) menyatakan bahwa suatu keberhasilan dalam bersaing merupakan sebuah kemampuan dari perusahaan dalam 
mencapai laba atau keuntungan ekonomis di atas laba yang dapat dicapai oleh perusahaan lain pada industri sejenis. Sehingga untuk lebih unggul dibandingkan dengan pesaing, suatu perusahaan membutuhkan sumber daya manusia yang memiliki kinerja yang baik agar menghasilkan produk yang berkualitas.

Sumber daya manusia merupakan salah satu faktor penting dalam suatu perusahaan (Hariandja, 2002). Maka sebuah perusahaan perlu memperhatikan pengelolaan sumber daya manusia yang baik agar dapat mewujudkan tujuan organisasi. Hasibuan (2000) mengatakan bahwa pengelolaan sumber daya manusia berarti penyiapan dan pelaksanaan suatu rencana yang terkoordinasi untuk menjamin bahwa sumber daya manusia yang ada dapat dimanfaatkan dengan sebaik-baiknya untuk mencapai tujuan organisasi. Agar dapat unggul dan bersaing dengan perusahaan lain, suatu perusahaan harus memiliki kinerja perusahaan yang baik. Garbutt (2010) mengatakan bahwa suatu perusahaan membutuhkan karyawan yang mempunyai kinerja yang tinggi.

Kinerja karyawan merupakan salah satu hal yang sangat penting dalam dunia industri baik itu di bidang manufaktur maupun jasa. Suatu perusahaan yang telah memiliki kinerja karyawan yang baik tentu saja akan memberikan kepuasan bagi konsumennya karena menurut Kotler (1997) kepuasan pelanggan merupakan tingkat perasaan yang dirasakan oleh konsumen setelah melakukan perbandingan kinerja atau hasil yang telah dibandingkan dengan harapannya. Untuk memenuhi kinerja karyawan yang baik, tentu saja karyawan harus memiliki kepuasan terhadap pekerjaan yang dilakukannya. Hubungan yang dimiliki antara kepuasan kerja dengan kinerja yang dihasilkan dari karyawan masih menjadi perdebatan dan menarik untuk diteliti lebih lanjut. Maka untuk memenuhi kepuasan karyawan, perusahaan perlu memperhatikan beberapa hal agar dapat berdampak baik bagi kinerja kerjanya. Di mana terdapat beberapa faktor yang menyebabkan kinerja yang diberikan karyawan kurang maksimal antara lain perlakuan yang tidak adil, imbalan yang diberikan kurang sesuai dengan volume pekerjaan yang dilakukan, bonus atau keuntungan yang diberikan kepada karyawan yang hanya pandai berbicara bukan berdasarkan target yang berhasil dicapai, serta beban kerja yang berlebihan.

Salah satu hal yang berpengaruh terhadap kinerja adalah kepuasan dalam hal kompensasi. Menurut Hariandja (2002), kompensasi yang diterima karyawan merupakan balas jasa dari pekerjaan yang telah dilakukan pada perusahaan yang berupa uang seperti gaji, upah, bonus, dan lain-lain. Karena menurut penelitian yang dilakukan oleh Paramitadewi (2017) semakin tinggi kompensasi yang diberikan kepada karyawan maka akan meningkatkan kinerja kerjanya. Terdapat beberapa indikator kompensasi menurut Simamora (2004) yaitu upah dan gaji, insentif, tunjangan, dan fasilitas.

Namun tidak hanya dari kompensasi saja, kinerja juga dipengaruhi oleh beban kerja yang diberikan kepada karyawannya. Beban kerja mental dapat diartikan sebagai evaluasi dari hasil pekerjaan yang dihasilkan terhadap kapasitas pekerjaan ketika karyawan dalam kondisi termotivasi dengan beban kerja yang diberikan (Hancock, 1998).

Dari faktor-faktor yang telah disebutkan tentu saja akan mempengaruhi motivasi kerja dari karyawan. Apabila karyawan memiliki motivasi yang tinggi tentu akan berpengaruh terhadap kinerja kerja yang dihasilkan karyawan karena menurut Munandar (2006) motivasi 
merupakan suatu keadaan di mana seseorang akan terdorong oleh kebutuhan-kebutuhan dalam melaksanakan pencapaian tujuan dari kegiatan tersebut.

Pada penelitian yang dilakukan oleh Oktaviana (2015) mengenai analisis faktor dengan menggunakan metode SEM, dilakukan untuk mengetahui hubungan antar faktor (variabel) yaitu beban kerja, komunikasi, dan motivasi yang mempengaruhi kinerja karyawan. Hasil dari penelitian ini memperlihatkan bahwa faktor yang mempengaruhi kinerja karyawan yaitu beban kerja. Penelitian ini hanya menggunakan metode SEM untuk melihat pengaruh antar variabelnya, namun tidak menghitung seberapa besar tingkat beban kerja dan motivasi kerja karyawannya. Dengan melakukan perhitungan terhadap tingkat beban kerja mental dan motivasi kerja maka dapat mengetahui seberapa besar beban kerja mental dan motivasi yang dirasakan oleh karyawan sehingga dapat menjadi pertimbangan dalam mengambil keputusan secara spesifik untuk perbaikan selanjutnya.

Pengukuran beban kerja pada sebuah perusahaan dengan menggunakan metode NASA-TLX dilakukan oleh Putri dan Handayani (2017). Hasil dalam penelitian tersebut memperlihatkan bahwa beban kerja yang dirasakan oleh karyawan pada perusahaan tersebut tergolong sedang. Selain beban kerja, pada penelitian Pujotomo et al. (2010) dilakukan pengukuran motivasi kerja terhadap pegawai panitia pengadaan di Dinas Pendidikan. Hasil dari penelitian tersebut memperlihatkan bahwa motivasi kerja pegawai panitia pengadaan secara keseluruhan dalam kategori sedang.

Penelitian-penelitian tersebut hanya melakukan pengukuran beban kerja mental dengan menggunakan metode NASA-TLX dan motivasi kerja dengan menggunakan metode JDS, namun tidak menghitung seberapa besar pengaruhnya terhadap kinerja pekerjaannya. Maka dalam penelitian ini dilakukan dengan menghubungkan metode SEM, NASA-TLX, dan JDS untuk melihat hubungan pengaruh antar variabel yaitu kompensasi, beban kerja, dan motivasi kerja terhadap kinerja karyawan dan melihat variabel mana yang paling berpengaruh terhadap kinerja karyawan. Kemudian dengan menggunakan metode NASA-TLX dapat dilakukan pengukuran tingkat beban kerja mental karyawan sehingga dapat mengetahui kategori beban kerja mental yang dirasakan karyawan. Beban kerja yang belum optimal dapat dilakukan pengukuran jumlah karyawan optimal. Selain beban kerja, penelitian ini juga mengukur tingkat motivasi kerja karyawan dengan menggunakan Metode JDS sehingga dapat diketahui tingkat motivasi kerja yang dirasakan oleh karyawan. Hasil yang diperoleh dari penelitian ini, dapat diketahui secara spesifik faktor-faktor yang menyebabkan kinerja karyawan kurang maksimal sehingga menjadi sebuah pertimbangan bagi perusahaan dalam mengambil keputusan untuk melakukan perbaikan.

\section{Model Building and Research Hypotheses Kompensasi}

Pemberian kompensasi dalam suatu perusahaan terhadap karyawannya sangat penting dan menjadi perhatian khusus bagi perusahaan. Perusahaan perlu menetapkan suatu kebijaksanaan dalam menentukan kompensasi yang diberikan dalam upaya meningkatkan kinerja. Kompensasi juga merupakan salah satu aspek yang sensitif dalam suatu hubungan kerja. Hariandja (2002) mengatakan bahwa kompensasi yang diterima karyawan merupakan balas jasa dari pekerjaan yang telah dilakukan pada perusahaan yang berupa uang seperti gaji, upah, bonus, dan lain-lain. Paramitadewi (2017) menyatakan semakin tinggi kompensasi yang diberikan kepada karyawan maka akan meningkatkan kinerja kerjanya. Apabila kompensasi 
dapat meningkatkan kinerja, maka pemberian kompensasi yang baik akan memberikan motivasi yang baik pula bagi karyawannya untuk bekerja. Semakin tinggi kompensasi yang diberikan akan memotivasi karyawan untuk bekerja lebih baik lagi (Ulfa, 2013). Maka dalam penelitian ini memiliki hipotesis sebagai berikut:

H1: Kompensasi berpengaruh terhadap motivasi kerja

H3: Kompensasi berpengaruh terhadap kinerja karyawan

\section{Beban Kerja Mental}

Beban kerja dapat dilihat dari jumlah pekerjaan yang harus diselesaikan oleh sekelompok atau seseorang pada jangka waktu tertentu melalui sudut pandang objektif dan subjektif (Moekijat, 2004). Beban kerja apabila dilihat dari sudut pandang objektif merupakan sejumlah waktu yang digunakan atau seberapa banyak pekerjaan yang dilakukan, sedangkan jika dilihat dari sudut pandang subjektif merupakan parameter yang digunakan seseorang mengenai bagaimana pernyataan terhadap perasaan beban kerja yang berlebih, maupun dari tekanan pekerjaan dan kepuasan kerja. Beban kerja yang dialami oleh pekerja jika terlalu berlebihan dapat menyebabkan timbulnya rasa lelah baik itu secara fisik maupun mental. Namun jika beban kerja yang diberikan kurang terhadap pekerjaan tersebut sedikit melakukan pergerakan maka akan timbul rasa bosan ketika bekerja. Beban kerja memiliki pengaruh terhadap motivasi kerja Anita et al. (2019). Tidak hanya mempengaruhi motivasi, beban kerja juga dapat mempengaruhi kinerja karyawan karena pekerjaan yang diberikan kepada karyawan akan mempengaruhi hasil dari pekerjaan yang dilakukan oleh karyawan. Beban kerja memiliki pengaruh yang negatif terhadap kinerja karyawan yang artinya apabila beban kerja yang diberikan terhadap karyawan semakin tinggi, maka akan menurunkan kinerja karyawannya (Paramitadewi, 2017). Maka dalam penelitian ini memiliki hipotesis:

H2: Beban kerja berpengaruh terhadap motivasi kerja

H4: Beban kerja berpengaruh terhadap kinerja karyawan

\section{Motivasi Kerja}

Dalam melakukan suatu pekerjaan, karyawan perlu memiliki motivasi yang baik sehingga karyawan tidak merasa terbebani ketika melakukan pekerjaan tersebut. Motivasi sendiri merupakan suatu kondisi di mana seseorang bersedia untuk mengeluarkan usaha yang tinggi untuk tujuan organisasi untuk memenuhi kebutuhannya. Motivasi merupakan suatu sikap seseorang untuk menimbulkan rasa puas terhadap hasil atas pekerjaan yang dilakukan (Robbins, 1996) sehingga motivasi dapat diartikan sebagai suatu dorongan atau keinginan yang timbul atau muncul dari dalam diri pekerja untuk melakukan pekerjaannya guna memunculkan rasa puas atas kinerjanya. Apabila karyawan memiliki motivasi yang tinggi dalam melakukan pekerjaannya maka kinerja kerjanya juga akan meningkat seperti yang diungkapkan oleh Taghipour dan Dejban (2013). Maka dalam penelitian ini memiliki hipotesis:

H5: Motivasi kerja berpengaruh terhadap kinerja karyawan

\section{METODE PENELITIAN}

Dalam suatu penelitian tentu harus memiliki variabel penelitian di mana variabel ini merupakan cerminan karakteristik populasi yang ingin diteliti. Dalam penelitian ini menggunakan variabel endogen dan eksogen. Variabel endogen merupakan variabel yang dipengaruhi oleh variabel independen, sehingga yang menjadi variabel endogen dalam 
penelitian ini adalah motivasi kerja dan kinerja karyawan. Sedangkan variabel eksogen merupakan variabel yang mempengaruhi variabel lainnya, maka dalam penelitian ini yang menjadi variabel eksogen adalah kompensasi dan beban kerja. Perancangan item pernyataan hanya dilakukan pada variabel kompensasi dan kinerja karyawan dikarenakan variabel beban kerja dan motivasi kerja sudah menggunakan kuesioner baku.

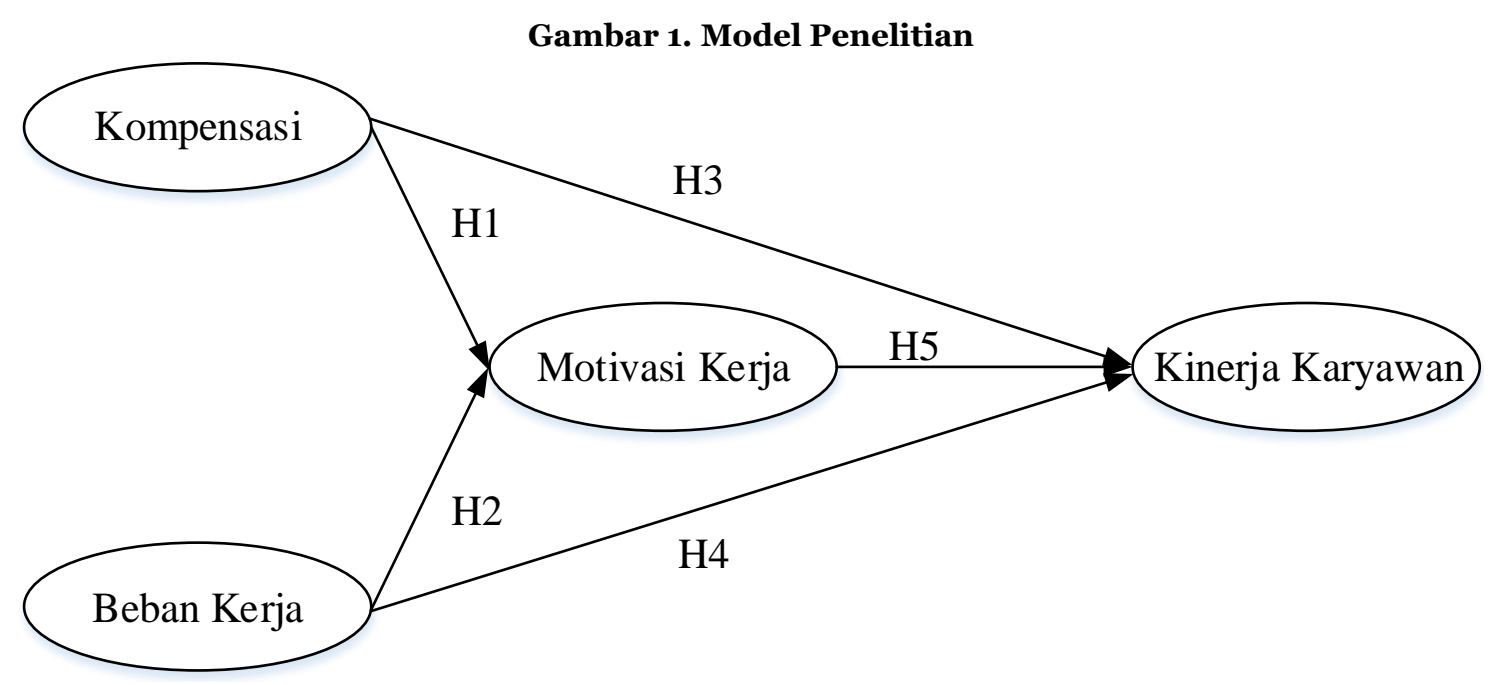

Sumber: Data Olahan Peneliti

Penelitian ini dilakukan di sebuah perusahaan kaca dengan menggunakan teknik sampling jenuh atau metode sensus sebanyak 183 responden yang merupakan seluruh karyawan yang bekerja di perusahaan tersebut bagian produksi. Berikut merupakan variabel dan indikator yang digunakan dalam penelitian.

Tabel 1. Variables and Indicators for Questionnaire

\begin{tabular}{|c|c|c|c|c|}
\hline Variabel Laten & Variabel Manifes & & Indikator & Referensi \\
\hline \multirow{8}{*}{$\begin{array}{l}\text { Compensation } \\
\text { (K) }\end{array}$} & Salary & K1 & Gaji dengan waktu bekerja & \multirow{8}{*}{$\begin{array}{l}\text { Simamora } \\
(2004)\end{array}$} \\
\hline & & $\mathrm{K} 2$ & $\begin{array}{l}\text { Gaji sesuai dengan } \\
\text { pekerjaan yang mereka } \\
\text { lakukan }\end{array}$ & \\
\hline & \multirow[t]{2}{*}{ Upah Insentif } & $\mathrm{K} 3$ & $\begin{array}{l}\text { Upah insentif dengan } \\
\text { waktu lembur }\end{array}$ & \\
\hline & & $\mathrm{K}_{4}$ & $\begin{array}{l}\text { Upah insentif dengan } \\
\text { pencapaian kerja }\end{array}$ & \\
\hline & \multirow[t]{2}{*}{ Tunjangan } & $\mathrm{K}_{5}$ & $\begin{array}{l}\text { Tunjangan sesuai dengan } \\
\text { tanggung jawab }\end{array}$ & \\
\hline & & K6 & $\begin{array}{l}\text { Tunjangan sesuai dengan } \\
\text { jabatan }\end{array}$ & \\
\hline & \multirow[t]{2}{*}{ Fasilitas } & $\mathrm{K}_{7}$ & $\begin{array}{l}\text { Fasilitas sesuai dengan } \\
\text { kebutuhan }\end{array}$ & \\
\hline & & K8 & $\begin{array}{l}\text { Fasilitas dapat } \\
\text { mendukung pekerjaan }\end{array}$ & \\
\hline \multirow{3}{*}{$\begin{array}{l}\text { Mental } \\
\text { Workload } \\
(\mathrm{BK})\end{array}$} & Mental Demand & BK1 & & \multirow{3}{*}{$\begin{array}{l}\text { Hancock dan } \\
\text { Meshkati } \\
\text { (1998) }\end{array}$} \\
\hline & Physical Demand & $\mathrm{BK} 2$ & & \\
\hline & Temporal Demand & $\mathrm{BK}_{3}$ & $\begin{array}{l}\text { Menggunakan kuesioner } \\
\text { NASA-TLX }\end{array}$ & \\
\hline
\end{tabular}




\begin{tabular}{|c|c|c|c|c|}
\hline & $\begin{array}{l}\text { Performance } \\
\text { Frustration } \\
\text { Effort }\end{array}$ & $\begin{array}{l}\mathrm{BK} 4 \\
\mathrm{BK} 5 \\
\mathrm{BK} 6\end{array}$ & & \\
\hline \multirow[t]{9}{*}{$\begin{array}{l}\text { Work } \\
\text { Motivation } \\
\text { (M) }\end{array}$} & Skill Variety & M2 & $\begin{array}{l}\text { Pekerjaan yang } \\
\text { membutuhkan } \\
\text { keterampilan } \\
\text { Pekerjaan yang } \\
\text { membutuhkan keahlian } \\
\text { khusus }\end{array}$ & $\begin{array}{l}\text { Hackman } \\
\text { dan Oldham } \\
(1974)\end{array}$ \\
\hline & \multirow[t]{2}{*}{ Task Identation } & M3 & $\begin{array}{l}\text { Pekerjaan berkaitan } \\
\text { dengan tanggung jawab }\end{array}$ & \\
\hline & & M4 & $\begin{array}{l}\text { Kesempatan untuk } \\
\text { melakukan pekerjaan dari } \\
\text { awal hingga akhir }\end{array}$ & \\
\hline & \multirow[t]{2}{*}{ Task Significant } & M5 & $\begin{array}{l}\text { Berpengaruh terhadap } \\
\text { kemajuan perusahaan }\end{array}$ & \\
\hline & & M6 & $\begin{array}{l}\text { Berpengaruh terhadap } \\
\text { hasil pekerjaan orang lain }\end{array}$ & \\
\hline & \multirow[t]{2}{*}{ Autonomy } & M7 & $\begin{array}{l}\text { Kebebasan dalam bekerja } \\
\text { tanpa pengawasan }\end{array}$ & \\
\hline & & M8 & $\begin{array}{l}\text { Kebebasan bekerja dengan } \\
\text { cara sendiri }\end{array}$ & \\
\hline & \multirow[t]{2}{*}{ Feedback } & M9 & $\begin{array}{l}\text { Umpan balik terhadap } \\
\text { hasil pekerjaan }\end{array}$ & \\
\hline & & M10 & $\begin{array}{l}\text { Kualitas pekerjaan dilihat } \\
\text { dari hasil pekerjaan yang } \\
\text { dilakukan }\end{array}$ & \\
\hline \multirow{10}{*}{$\begin{array}{l}\text { Employee } \\
\text { Performance } \\
\text { (H) }\end{array}$} & Quantity & H1 & Mencapai target produksi & Mathis (2011) \\
\hline & \multirow[t]{2}{*}{ Quality } & $\mathrm{H} 2$ & $\begin{array}{l}\text { Kualitas sesuai dengan } \\
\text { harapan perusahaan }\end{array}$ & \\
\hline & & $\mathrm{H}_{3}$ & $\begin{array}{l}\text { Kualitas hasil di atas rata- } \\
\text { rata target }\end{array}$ & \\
\hline & \multirow[t]{2}{*}{ Ketepatan Waktu } & $\mathrm{H}_{4}$ & $\begin{array}{l}\text { Menyelesaikan pekerjaan } \\
\text { tepat waktu }\end{array}$ & \\
\hline & & $\mathrm{H}_{5}$ & $\begin{array}{l}\text { Menyelesaikan pekerjaan } \\
\text { dengan memperhatikan } \\
\text { efisiensi waktu }\end{array}$ & \\
\hline & \multirow[t]{3}{*}{ Kehadiran } & H6 & Disiplin & \\
\hline & & $\mathrm{H}_{7}$ & $\begin{array}{l}\text { Ketidakhadiran saya tidak } \\
\text { melebihi batas yang } \\
\text { ditentukan }\end{array}$ & \\
\hline & & H8 & $\begin{array}{l}\text { Kehadiran kerja adalah } \\
\text { hal penting }\end{array}$ & \\
\hline & \multirow[t]{2}{*}{ Team Work } & H9 & $\begin{array}{l}\text { Dapat bekerja sama } \\
\text { dengan atasan }\end{array}$ & \\
\hline & & H10 & $\begin{array}{l}\text { Dapat bekerja sama } \\
\text { dengan sesama karyawan }\end{array}$ & \\
\hline
\end{tabular}


Setelah merancang kuesioner dan menentukan sampling yang digunakan maka selanjutnya adalah melakukan penyebaran kuesioner kepada 50 responden untuk dilakukan uji validitas dan reliabilitas. Uji ini dilakukan untuk mengetahui apakah kuesioner yang disebarkan kepada responden dapat digunakan sebagai alat ukur dalam penelitian ini. Pengujian validitas dan reliabilitas ini dilakukan dengan menggunakan software SPSS 17.0. Jika kuesioner yang digunakan sudah valid dan reliable maka dapat digunakan dalam penelitian dan disebarkan kepada 183 responden.

Pengukuran tingkat beban kerja mental menggunakan metode NASA-TLX. Langkah pertama yang dilakukan adalah dengan memilih salah satu dari pasangan indikator yang mana menurut karyawan tersebut lebih dominan mereka alami saat bekerja. Kemudian tahap selanjutnya adalah dengan memberikan nilai atau rating terhadap masing-masing indikator beban mental. Hasil rekapitulasi nilai bobot dengan nilai rating kemudian dikalikan akan menghasilkan nilai weight workload (WWL). Rata-rata WWL didapat dengan membagi nilai WWL dengan jumlah bobot total yaitu 15 .

$$
\text { Average } \mathrm{WWL}=\frac{\mathrm{MD}+\mathrm{PD}+\mathrm{TD}+\mathrm{P}+\mathrm{F}+\mathrm{E}}{15}
$$

Nilai rata-rata WWL ini merupakan tingkat beban kerja mental dari responden. Hasil nilai rata-rata WWL dikategorikan dalam 5 kelompok yaitu sangat rendah, rendah, sedang, tinggi, dan sangat tinggi. Berikut merupakan tabel kategori tingkat beban kerja mental.

Tabel 2. Kategori Beban Kerja Mental

\begin{tabular}{ccl}
\hline No. & Nilai Rata-Rata WWL & Kategori Beban Kerja \\
\hline 1 & $0-20$ & Sangat Rendah \\
2 & $21-40$ & Rendah \\
3 & $41-60$ & Sedang \\
4 & $61-80$ & Tinggi \\
5 & $81-100$ & Sangat Tinggi \\
\hline \multicolumn{3}{c}{ Sumber: Umyati et al. (2013) }
\end{tabular}

Dari nilai beban kerja mental ini dapat dilakukan perhitungan jumlah karyawan optimal. Apabila beban mental tinggi maka perlu dilakukan penambahan jumlah karyawan agar optimal begitu pun sebaliknya. Perhitungan dilakukan dengan menjumlahkan nilai bobot $\mathrm{x}$ rating dibagi dengan batas atas beban kerja yang optimal yaitu 60.

$$
\text { Jumlah Karyawan Optimal }=\frac{\text { Total Rata }- \text { Rata Beban Kerja Mental }}{\text { Rata }- \text { Rata Beban Kerja Mental }}
$$

Pengukuran motivasi kerja menggunakan metode Job Diagnostic Survey (JDS). Langkah pertama yang dilakukan adalah menghitung rata-rata untuk masing-masing item pernyataan. Kemudian dilakukan perhitungan rata-rata untuk masing-masing variabel dari nilai rata-rata item pernyataan yang telah dilakukan. Setelah didapat nilai rata-rata dari masing-masing variabel, maka dilakukan perhitungan nilai Motivational Potential Score (MPS) dengan menjumlahkan dimensi variasi keterampilan, identitas tugas, dan signifikansi tugas kemudian dibagi 3 dan dikalikan dengan nilai otonomi dan umpan balik. 


$$
\text { MPS }=\frac{(\text { variety }+ \text { identity }+ \text { significance })}{3} \times \text { autonomy } \times \text { feedback }
$$

Nilai MPS yang didapat akan digunakan untuk melihat kategori tingkat motivasi kerja karyawan. Tingkat motivasi kerja dikategorikan dalam 3 kelompok yaitu kategori rendah dengan nilai MPS sebesar 1-16, kategori sedang dengan nilai MPS sebesar 17-43, dan kategori tinggi dengan nilai MPS sebesar 44-125. Selanjutnya untuk mengetahui hubungan antar variabel digunakan metode SEM. Input data yang digunakan merupakan rekapitulasi kuesioner penelitian. Kemudian data tersebut diolah dengan menggunakan software LISREL 8.70 dan menghasilkan output yaitu path diagram, structural equation, dan goodness of fit.

\section{HASIL DAN PEMBAHASAN}

\section{Analisis Karakteristik Responden}

Responden dalam penelitian ini seluruhnya berjenis kelamin laki-laki karena pada bagian produksi memiliki lingkungan kerja dengan temperatur tinggi dan pekerjaan yang menuntut fisik yang kuat. Sebagian besar usia responden adalah $>41$ tahun dengan persentase sebesar 69.95\% dan sebagian besar berpendidikan SMA sederajat dengan persentase sebesar 93.99\%. Berdasarkan jabatan terakhir menunjukkan bahwa posisi jabatan responden terbanyak adalah karyawan (general employee) dengan persentase sebesar $89.07 \%$ dan gaji yang diterima sebagian besar adalah Rp. 4.000.000,00 - Rp. 4.900.000,00 per bulannya dengan persentase sebesar $77.05 \%$.

\section{Hasil Beban Kerja Mental dan Jumlah Karyawan Optimal}

Tabel 3. Result of Mental Workload

\begin{tabular}{lcc}
\hline \multicolumn{1}{c}{ Division } & Average of WWL & Conclusion \\
\hline TQA & 73.69 & High \\
Furnace & 79.94 & High \\
Tinbath and Annealing & 75.63 & High \\
Cutting Line & 71.69 & High \\
Warehouse & 72.95 & High \\
\hline Rata-Rata WWL Bagian & 74.78 & High \\
Produksi &
\end{tabular}

Setelah dilakukan pengolahan data dengan menggunakan metode NASA-TLX didapat hasil bahwa rata-rata WWL bagian produksi yaitu 74.78 yang artinya memiliki tingkat beban kerja mental tinggi dengan nilai rata-rata WWL untuk masing-masing divisi yaitu TQA sebesar 73.69, furnace sebesar 79.94, tinbath \& annealing sebesar 75.63, cutting line sebesar 71.69, dan warehouse sebesar 72.95. Divisi yang memiliki tingkat beban kerja mental tinggi yaitu furnace dengan nilai rata-rata WWL sebesar 79.94. Pada divisi furnace indikator beban kerja mental tertinggi adalah mental demand dengan nilai total bobot x rating adalah 4150. Mental demand merupakan seberapa besar aktivitas mental yang dibutuhkan untuk melihat, mengingat, dan mencari. Pada divisi ini karyawan dituntut untuk selalu mengontrol dan mengawasi temperatur dari dapur yang digunakan untuk membuat kaca. Temperatur tersebut harus tetap dijaga karena mempengaruhi kualitas dari kaca yang dihasilkan. Temperatur dapur yang baik adalah $1600^{\circ} \mathrm{C}$ sehingga jika lebih dari suhu tersebut maka batu dapur bisa 
rusak dan meleleh, namun jika suhu terlalu rendah, maka material yang dipanaskan tidak meleleh secara sempurna sehingga dapat menyebabkan defect pada kaca yang dihasilkan dan tentu saja dapat menurunkan kualitas dari kaca tersebut.

Tabel 4. Hasil Jumlah Karyawan Optimal

\begin{tabular}{lccc}
\hline \multirow{2}{*}{ Divisi } & \multicolumn{3}{c}{ Jumlah Penambahan } \\
\cline { 2 - 4 } & Aktual & Optimal & Penambahan \\
\hline TQA & 16 & 20 & 4 \\
Furnace & 16 & 22 & 6 \\
Tinbath and Annealing & 32 & 41 & 9 \\
Cutting Line & 79 & 95 & 16 \\
Warehouse & 40 & 49 & 9 \\
\hline \multicolumn{4}{c}{ Sumber: Data olahan peneliti }
\end{tabular}

Setelah mengetahui tingkat beban kerja mental yang dialami karyawan yaitu termasuk kategori tinggi maka perlu dilakukan perhitungan jumlah karyawan optimal. Pada divisi TQA perlu menambahkan 4 karyawan, furnace perlu menambahkan 6 karyawan, tinbath \& annealing perlu menambahkan 9 karyawan, cutting line perlu menambahkan 16 karyawan, dan warehouse perlu menambahkan 9 karyawan.

\section{Hasil Motivasi Kerja}

Tabel 5. Result of Work Motivation

\begin{tabular}{ccc}
\hline Division & MPS & Conclusion \\
\hline TQA & 38.17 & Medium \\
Furnace & 38.49 & Medium \\
Tinbath and Annealing & 51.86 & High \\
Cutting Line & 55.92 & High \\
Warehouse & 44.94 & High \\
\hline Rata-Rata Nilai MPS & 45.88 & High \\
Bagian Produksi & \\
\hline \multicolumn{2}{c}{ Sumber: Data olahan peneliti }
\end{tabular}

Berdasarkan perhitungan yang dilakukan dengan menggunakan metode JDS didapat hasil bahwa divisi TQA dan furnace memiliki tingkat motivasi sedang yaitu 38.17 dan 38.49 sedangkan untuk divisi tinbath \& annealing, cutting line, dan warehouse memiliki tingkat motivasi tinggi yaitu 51.86, 55.92, dan 44.94 maka karyawan pada bagian produksi ini memiliki tingkat motivasi yang tinggi. Divisi yang memiliki tingkat motivasi terendah adalah divisi TQA dengan indikator terendahnya yaitu otonomi dengan nilai rata-rata 2.81 karena karyawan tidak memiliki kebebasan dalam melakukan pekerjaannya karena dibatasi oleh target waktu dan ketelitian dalam melakukan pekerjaannya di mana pekerjaan yang mereka lakukan harus sesuai dengan standar SOP yang berlaku di perusahaan.

Hasil Structural Equation Modelling (SEM)

Gambar 2. Path Diagram Standarized Solution 


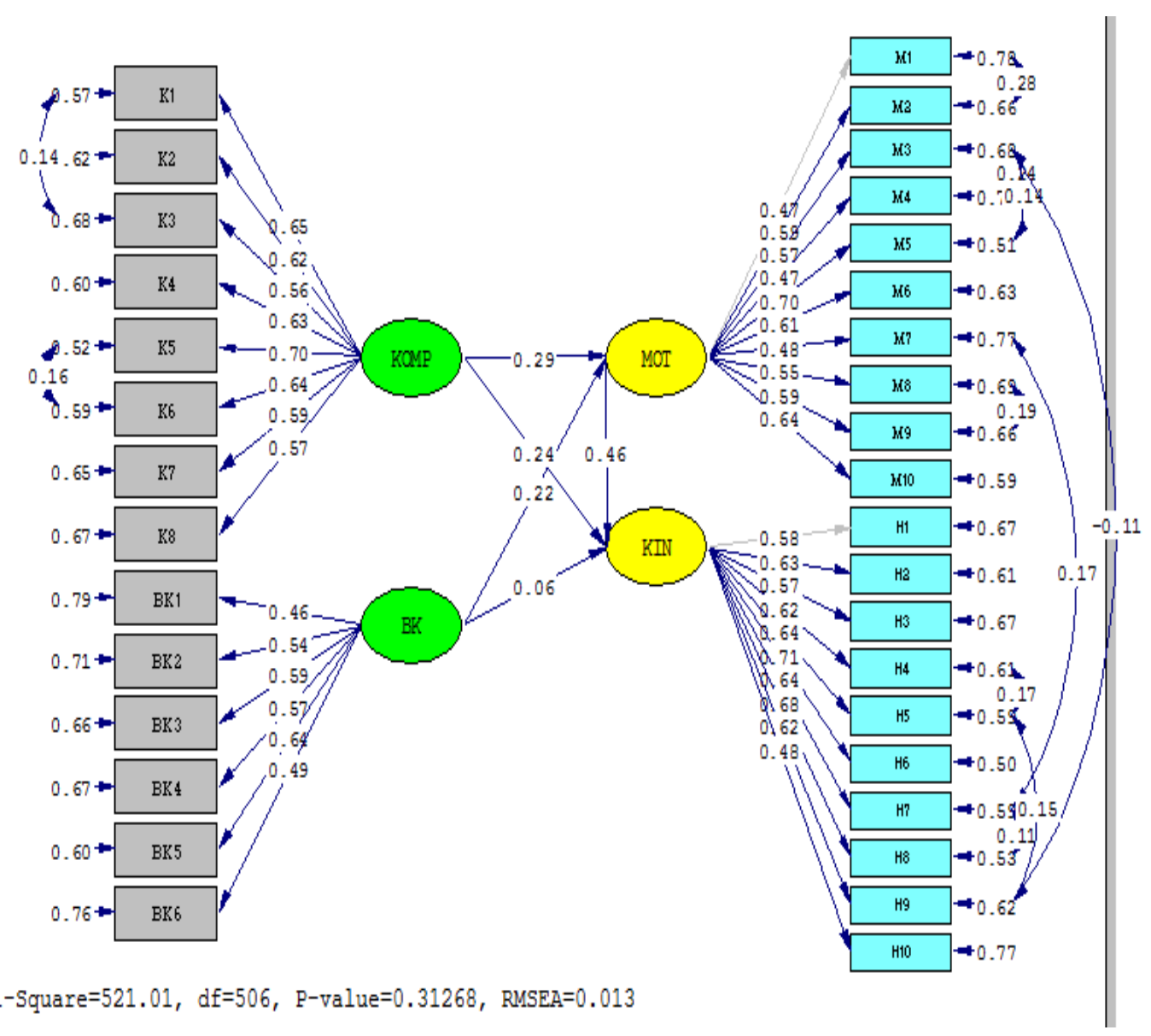

Sumber: Data olahan peneliti

Dari gambar path diagram di atas dapat dilakukan pengujian kecocokan model measurement model untuk mengetahui reliability gabungan untuk masing-masing variabel laten dengan cara menghitung nilai construct reliability. Didapat hasil bahwa seluruh variabel laten memiliki nilai CR lebih besar dari 0.7 yaitu kompensasi $=0.83$, beban kerja mental $=0.72$, motivasi kerja $=0.77$, dan kinerja karyawan $=0.86$.

Tabel 6. Hasil Perhitungan Reliability and Variance Extracted

\begin{tabular}{lcccccc}
\hline & $\mathrm{LF}$ & $\mathrm{LF}^{2}$ & $\varepsilon \mathrm{j}$ & $\left(\sum L F\right)^{2}$ & $\begin{array}{c}\text { Construct } \\
\text { Reliability }\end{array}$ & $\begin{array}{c}\text { Variance } \\
\text { Extracted }\end{array}$ \\
\hline Compensation & & & & 24.60 & 0.83 & 0.39 \\
$\mathrm{~K} 1$ & 0.65 & 0.42 & 0.57 & & & \\
$\mathrm{~K} 2$ & 0.62 & 0.38 & 0.62 & & & \\
$\mathrm{~K} 3$ & 0.56 & 0.31 & 0.68 & & & \\
$\mathrm{~K} 4$ & 0.63 & 0.40 & 0.60 & & \\
$\mathrm{~K} 5$ & 0.70 & 0.49 & 0.52 & & & \\
$\mathrm{~K} 6$ & 0.64 & 0.41 & 0.59 & & & \\
$\mathrm{~K} 7$ & 0.59 & 0.35 & 0.65 & & &
\end{tabular}


K8

$\begin{array}{lll}0.57 & 0.32 & 0.67\end{array}$

Mental Workload

10.82

0.72

0.3

BK1

$\begin{array}{lll}0.46 & 0.212 & 0.79\end{array}$

$\mathrm{BK} 2$

$\begin{array}{lll}0.54 & 0.292 & 0.71\end{array}$

$\mathrm{BK}_{3}$

$\begin{array}{lll}0.59 & 0.348 & 0.66\end{array}$

BK4

$\begin{array}{lll}0.57 & 0.325 & 0.67\end{array}$

BK5

$\begin{array}{lll}0.64 & 0.41 & 0.6\end{array}$

BK6

0.49

$0.24 \quad 0.76$

Work Motivation

12.74

0.77

0.22

M1

$\begin{array}{lll}0.47 & 0.221 & 0.78\end{array}$

M2

$\begin{array}{lll}0.59 & 0.348 & 0.66\end{array}$

M3

$\begin{array}{lll}0.57 & 0.325 & 0.68\end{array}$

M4

$\begin{array}{lll}0.47 & 0.221 & 0.78\end{array}$

M5

$\begin{array}{lll}0.7 & 0.49 & 0.51\end{array}$

M6

$\begin{array}{lll}0.61 & 0.372 & 0.63\end{array}$

M7

$\begin{array}{lll}0.48 & 0.23 & 0.77\end{array}$

M8

$\begin{array}{lll}0.55 & 0.303 & 0.69\end{array}$

M9

$\begin{array}{lll}0.59 & 0.348 & 0.66\end{array}$

M10

$\begin{array}{lll}0.64 & 0.41 & 0.59\end{array}$

Employee Performance

$\begin{array}{lll}38.07 & 0.86 & 0.38\end{array}$

\begin{tabular}{llll}
$\mathrm{H} 1$ & 0.58 & 0.336 & 0.67 \\
$\mathrm{H} 2$ & 0.63 & 0.397 & 0.61 \\
$\mathrm{H} 3$ & 0.57 & 0.325 & 0.67 \\
$\mathrm{H} 4$ & 0.62 & 0.384 & 0.61 \\
$\mathrm{H} 5$ & 0.64 & 0.41 & 0.59 \\
$\mathrm{H} 6$ & 0.71 & 0.504 & 0.5 \\
$\mathrm{H} 7$ & 0.64 & 0.41 & 0.59 \\
$\mathrm{H} 8$ & 0.68 & 0.462 & 0.53 \\
$\mathrm{H} 9$ & 0.62 & 0.384 & 0.62 \\
$\mathrm{H} 10$ & 0.48 & 0.23 & 0.77 \\
\hline LF, loading factor & \multicolumn{3}{r}{ Sumber: Data olahan peneliti }
\end{tabular}




\section{Gambar 3. Path Diagram T-Value}

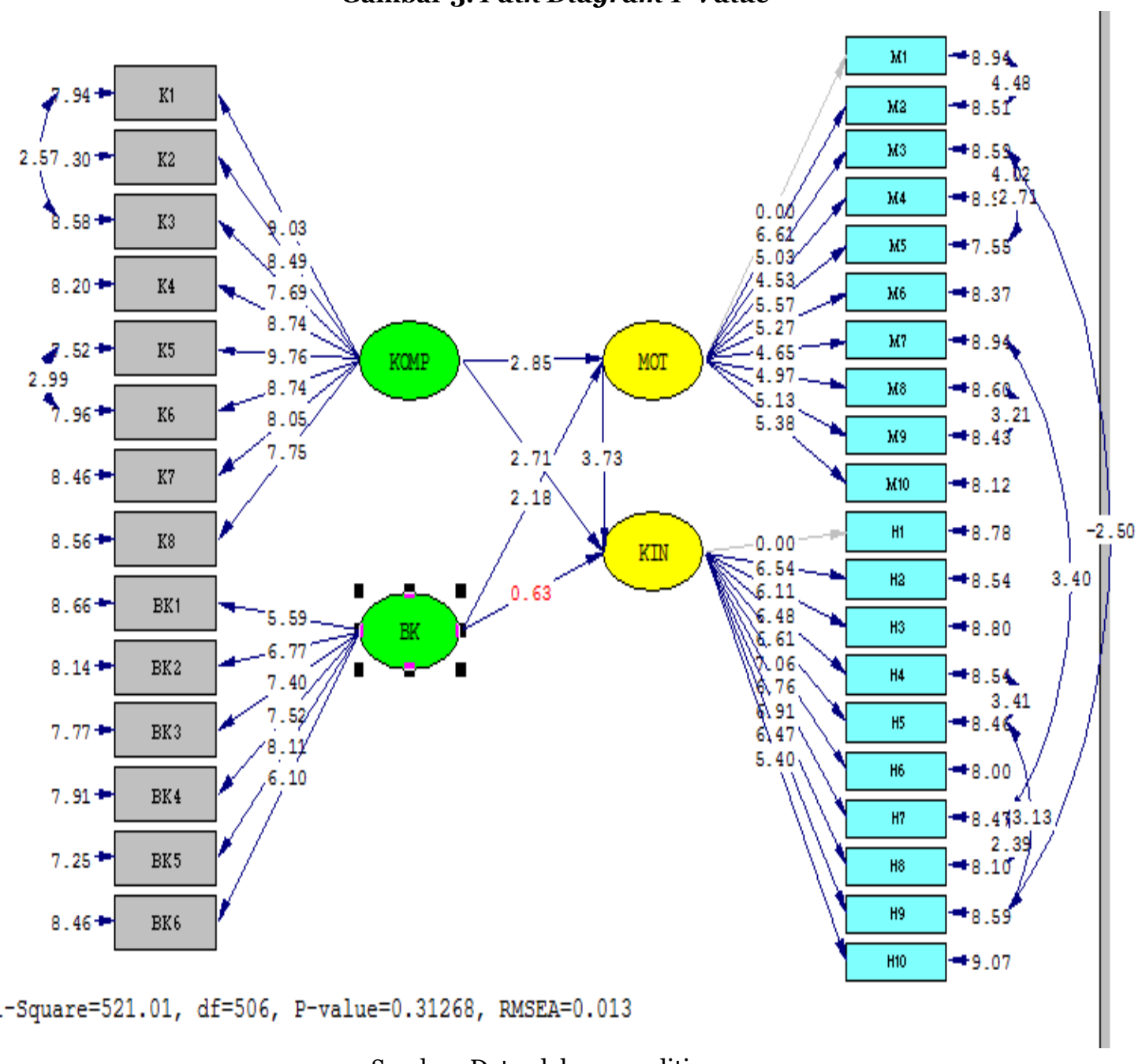

Sumber: Data olahan peneliti

Path diagram T-value di atas menunjukkan hubungan pengaruh dari suatu variabel terhadap variabel lainnya di mana hubungan-hubungan tersebut merupakan hipotesis yang diajukan dalam penelitian. Tingkat signifikan pada uji $t$ ini adalah 5\% (o.05) maka nilai t agar dapat diterimanya suatu hubungan adalah lebih besar sama dengan 1.96. Berikut merupakan hasil t-value hubungan antar variabel:

(1) KOMP terhadap MOT $=2.85>1.96$

Dapat disimpulkan bahwa hubungan kompensasi dengan motivasi kerja adalah signifikan.

(2) BK terhadap MOT $=2.18>1.96$

Dapat disimpulkan bahwa hubungan beban kerja mental dengan motivasi kerja adalah signifikan.

(3) KOMP terhadap KIN $=2.71>1.96$

Dapat disimpulkan bahwa hubungan kompensasi dengan kinerja karyawan adalah signifikan.

(4) BK terhadap $\mathrm{KIN}=0.63<1.96$

Dapat disimpulkan bahwa hubungan beban kerja mental dengan kinerja karyawan adalah tidak signifikan.

(5) MOT terhadap KIN $=3.73>1.96$

Dapat disimpulkan bahwa hubungan motivasi kerja dengan kinerja karyawan adalah signifikan. 
Pengujian nilai t juga dapat dilakukan pada masing-masing indikator variabel laten dengan melihat indikator masing-masing variabel memiliki nilai bobot faktor lebih besar dari 1.96 maka dapat disimpulkan bahwa setiap indikator dari masing-masing variabel laten adalah signifikan.

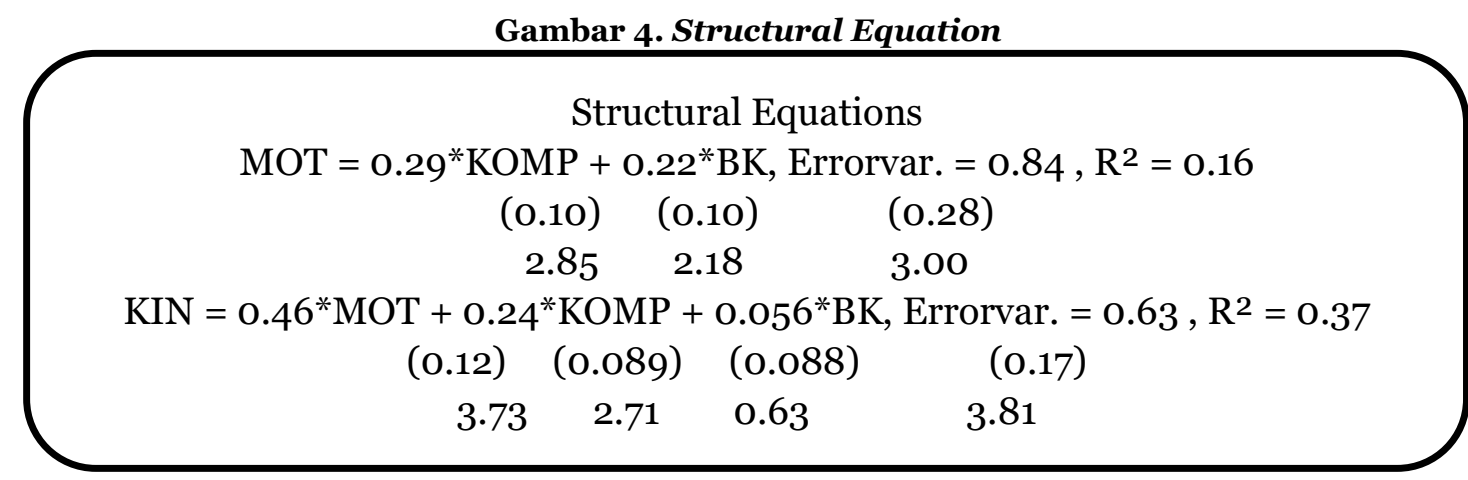

Sumber: Data olahan peneliti

Squared multiple correlation atau koefisien determinasi $\left(\mathrm{R}^{2}\right)$ menunjukkan seberapa besar variasi dari variabel terikat dapat dijelaskan oleh variabel bebas. Besarnya nilai $\mathrm{R}^{2}$ berkisar antara 0-1 dan selalu positif. Semakin tinggi nilai $\mathrm{R}^{2}$ maka pengaruh tersebut semakin kuat. Namun jika nilai $\mathrm{R}^{2}$ bernilai negatif (-) maka dapat dikatakan bahwa tidak terdapat pengaruh variabel dependen terhadap variabel independen. Pada gambar di atas menunjukkan hasil sebagai berikut:

(1) $\quad$ Nilai $\mathrm{R}^{2} \mathrm{KOMP} \rightarrow \mathrm{MOT}$ dan $\mathrm{BK} \rightarrow \mathrm{MOT}=0.16$

Artinya bahwa $16 \%$ varians pada variabel motivasi kerja dijelaskan oleh variabel kompensasi dan beban kerja mental. Sedangkan 84\% lainnya dijelaskan oleh variabel selain kompensasi dan beban kerja mental.

(2) $\quad$ Nilai $\mathrm{R}^{2} \mathrm{KOMP} \rightarrow \mathrm{KIN}, \mathrm{BK} \rightarrow \mathrm{KIN}$, dan $\mathrm{MOT} \rightarrow \mathrm{KIN}=0.37$

Artinya bahwa $36 \%$ varians pada variabel kinerja karyawan dijelaskan oleh variabel kompensasi, beban kerja mental, dan motivasi kerja. Sedangkan 63\% lainnya dijelaskan oleh variabel selain kompensasi, beban kerja mental, dan motivasi kerja.

Tabel 7. Goodness of Fit

\begin{tabular}{|c|c|c|c|c|c|}
\hline \multirow{2}{*}{\multicolumn{2}{|c|}{ GOF Measurement }} & \multirow[b]{2}{*}{ Parameter } & \multicolumn{2}{|c|}{ Hasil Estimasi } & \multirow{2}{*}{$\begin{array}{l}\text { Tingkat } \\
\text { Kecocokan }\end{array}$} \\
\hline & & & $\begin{array}{c}\text { Before } \\
\text { Modification }\end{array}$ & $\begin{array}{c}\text { After } \\
\text { Modification }\end{array}$ & \\
\hline \multirow{4}{*}{\multicolumn{2}{|c|}{$\begin{array}{c}\text { Chi-Square } \\
\text { P-Value } \\
\text { NCP }\end{array}$}} & $<3$ & 758.61 & 580.36 & unfit \\
\hline & & $\mathrm{p} \geq 0.05$ & o & 0.012 & unfit \\
\hline & & Nilai yang kecil & 169.54 & 15.01 & fit \\
\hline & & interval & $105 \cdot 33 ; 241.83$ & $0.0 ; 73.13$ & \\
\hline \multirow{2}{*}{\multicolumn{2}{|c|}{$\begin{array}{c}\text { RMSEA } \\
\text { P (close fit) }\end{array}$}} & RMSEA $\leq 0.05$ & 0.042 & 0.013 & fit \\
\hline & & $\mathrm{P} \geq 0.5$ & 0.94 & 1 & fit \\
\hline \multirow[t]{3}{*}{ ECVI } & Model & Model ECVI & 4.61 & 3.84 & fit \\
\hline & Saturated & mendekati & 6.54 & 6.54 & \\
\hline & Independence & saturated ECVI & 28.64 & 28.64 & \\
\hline \multirow[t]{2}{*}{ AIC } & Model & & 838.54 & 699.01 & fit \\
\hline & Saturated & & 1190 & 1190 & \\
\hline
\end{tabular}




\begin{tabular}{|c|c|c|c|c|c|}
\hline & Independence & $\begin{array}{c}\text { Model AIC } \\
\text { mendekati } \\
\text { saturated AIC }\end{array}$ & 5212 & 5212 & \\
\hline \multirow[t]{3}{*}{ CAIC } & Model & Model CAIC & 1150.04 & 1073.66 & \multirow[t]{3}{*}{ fit } \\
\hline & \multirow{2}{*}{$\begin{array}{c}\text { Saturated } \\
\text { Independence }\end{array}$} & \multirow{2}{*}{$\begin{array}{c}\text { mendekati } \\
\text { saturated CAIC }\end{array}$} & 3694.64 & 3694.64 & \\
\hline & & & 5355.12 & 5355.12 & \\
\hline & NFI & $\geq 0.90$ & 0.85 & 0.89 & $\begin{array}{l}\text { marginal } \\
\text { fit }\end{array}$ \\
\hline & NNFI & $\geq 0.90$ & 0.94 & 0.98 & fit \\
\hline & CFI & $\geq 0.90$ & 0.95 & 0.98 & fit \\
\hline & IFI & $\geq 0.90$ & 0.95 & 0.98 & fit \\
\hline & RFI & $\geq 0.90$ & 0.84 & 0.87 & $\begin{array}{l}\text { marginal } \\
\text { fit }\end{array}$ \\
\hline & $\mathrm{CN}$ & $\geq 200$ & 144.71 & 183.81 & $\mathrm{~s}$ \\
\hline & RMRS & $\mathrm{RMRS} \leq 0.05$ & 0.063 & 0.051 & $\begin{array}{l}\text { marginal } \\
\text { fit }\end{array}$ \\
\hline & GFI & $\geq 0.90$ & 0.82 & 0.86 & $\begin{array}{l}\text { marginal } \\
\text { fit }\end{array}$ \\
\hline & AGFI & $\geq 0.9$ & 0.79 & 0.83 & $\begin{array}{l}\text { marginal } \\
\text { fit }\end{array}$ \\
\hline
\end{tabular}

Sumber: Data olahan peneliti

Berdasarkan hasil rekapitulasi kecocokan goodness of fit model keseluruhan dapat dilihat bahwa terdapat 3 dari 17 ukuran GOF yang menunjukkan hasil tidak fit yaitu sebesar 18\% dari total ukuran GOF yaitu ukuran Chi-Square, p-value, NCP, CN, RMRS, dan AGFI sehingga 82\% model fit. Dalam penelitian sangat kecil kemungkinannya untuk menemukan kecocokan pada setiap ukuran GOF sehingga apabila sebagian besar dari ukuran GOF menunjukkan hasil yang baik atau fit (model fit > 50\%) maka dapat disimpulkan bahwa model adalah baik karena model telah menggambarkan kondisi aktualnya (Ghozali \& Fuad, 2005).

\section{Analisis Hipotesis \\ Implikasi Teoritis}

Pengujian hipotesis digunakan untuk mengambil suatu keputusan yang didasarkan dari analisis data. Pengujian hipotesis ini dilakukan dengan menggunakan model persamaan struktural SEM dengan software LISREL 8.70 dengan cara membandingkan nilai t hitung dari hasil pengolahan data. $T$ tabel yang digunakan yaitu signifikansi $0.05(5 \%)=1.96$. Dasar pengambilan keputusan pengujian hipotesis ini adalah sebagai berikut:

Jika nilai t hitung < t tabel, maka terima Ho

Jika nilai t hitung $>\mathrm{t}$ tabel, maka tolak Ho

Hasil pengujian hipotesis kompensasi terhadap motivasi kerja menunjukkan nilai t hitung lebih besar daripada nilai t tabel dan bernilai positif sehingga dapat disimpulkan bahwa kompensasi berpengaruh positif terhadap motivasi kerja. Semakin tinggi kompensasinya maka semakin besar motivasi kerja karyawan tersebut. Hal ini sesuai dengan penelitian yang dilakukan oleh Ulfa (2013) yang menunjukkan hasil bahwa kompensasi memiliki pengaruh yang signifikan positif terhadap motivasi karyawan sehingga semakin dilaksanakan dengan baik kompensasi kepada karyawan maka akan dapat memotivasi karyawan untuk bekerja lebih baik lagi. 
Hasil pengujian hipotesis beban kerja mental terhadap motivasi kerja menunjukkan nilai t hitung lebih besar daripada nilai t tabel dan bernilai positif sehingga dapat disimpulkan bahwa beban kerja mental berpengaruh positif terhadap motivasi kerja. Hal ini didukung dengan penelitian yang dilakukan oleh Anita et al. (2019) yang menunjukkan bahwa adanya pengaruh positif dan signifikan antara beban kerja terhadap motivasi kerja, di mana semakin besar beban kerja mental yang diberikan kepada karyawan maka akan meningkatkan motivasi kerja karyawan dalam melakukan pekerjaannya. Karyawan memiliki penilaian yang positif mengenai sejumlah tuntutan pekerjaan yang harus mereka kerjakan dalam waktu tertentu sehingga karyawan akan menganggap beban kerja sebagai tantangan dalam bekerja. Maka dari itu karyawan akan termotivasi dan lebih bersungguh-sungguh dalam melakukan pekerjaannya dan menghasilkan sesuatu yang bermanfaat bagi dirinya dan untuk kemajuan perusahaan.

Hasil pengujian hipotesis kompensasi terhadap kinerja karyawan menunjukkan nilai t hitung lebih besar daripada nilai $t$ tabel dan bernilai positif sehingga dapat disimpulkan bahwa kompensasi berpengaruh positif terhadap kinerja karyawan. Hal ini didukung dengan penelitian yang dilakukan oleh Paramitadewi (2017) yang menunjukkan bahwa kompensasi memiliki pengaruh positif dan signifikan terhadap kinerja karyawan sehingga semakin tinggi kompensasi yang diberikan kepada karyawan oleh perusahaan maka akan dapat meningkatkan kinerja kerja karyawannya.

Hasil pengujian hipotesis beban kerja mental terhadap kinerja karyawan menunjukkan nilai t hitung lebih kecil daripada nilai t tabel sehingga dapat disimpulkan bahwa beban kerja mental tidak berpengaruh terhadap kinerja karyawan. Hal ini sesuai dengan penelitian yang dilakukan oleh Omolayo (2013) yang menyatakan bahwa tidak adanya hubungan yang signifikan antara beban kerja mental dengan kinerja karyawan. Hal ini dijelaskan bahwa peningkatan atau penurunan permintaan tugas tidak mempengaruhi kinerja pekerja karena mereka sedang bekerja menuju realisasi dan pencapaian tujuan organisasi. Ketelitian dan responsif karyawan terhadap pekerjaannya, pengetahuan karyawan tentang pekerjaan, dan motivasi serta dukungan yang diterima tidak dapat dihambat oleh permintaan pekerjaan. Hubungan ini tidak memiliki pengaruh karena karyawan yang bekerja pada bagian produksi hanya melaksanakan tanggung jawabnya untuk menyelesaikan pekerjaan yang dilakukan sehingga besar kecilnya beban kerja mental tidak akan mempengaruhi kinerja kerjanya.

Hasil pengujian hipotesis motivasi kerja terhadap kinerja karyawan menunjukkan nilai t hitung lebih besar daripada nilai t tabel dan bernilai positif sehingga dapat disimpulkan bahwa motivasi kerja berpengaruh positif terhadap kinerja karyawan. Hal ini sesuai dengan penelitian yang dilakukan oleh Imlawal \& Winarningsih (2016) bahwa terdapat pengaruh positif antar motivasi kerja terhadap kinerja karyawan. Penelitian ini sesuai dengan pernyataan Kasmir (2016) yang menyatakan bahwa semakin termotivasi seseorang dalam melakukan suatu pekerjaan maka kinerjanya juga akan meningkat, demikian pula sebaliknya apabila seseorang semakin tidak termotivasi untuk melakukan pekerjaannya, maka kinerjanya akan menurun.

\section{Implikasi Manajerial}

Penelitian ini untuk mengetahui analisis hubungan antar variabel yang mempengaruhi kinerja karyawan dan mengetahui variabel manakah yang mempunyai pengaruh terbesar pada 
kinerja karyawan. Variabel yang digunakan dalam penelitian ini adalah kompensasi, beban kerja, motivasi kerja, dan kinerja karyawan. Perhitungan tingkat beban kerja mental menunjukkan hasil bahwa karyawan yang bekerja pada perusahaan tersebut berada dalam kategori beban kerja mental tinggi sehingga perlu dilakukan perhitungan jumlah karyawan optimal agar dengan dilakukan penambahan jumlah karyawan dapat mengurangi tingkat beban kerja mental.

Motivasi kerja merupakan salah satu variabel yang mempengaruhi kinerja karyawan. Berdasarkan hasil perhitungan dengan metode JDS, pada divisi TQA dan furnace masih memiliki motivasi kerja yang sedang sehingga perusahaan perlu menjaga motivasi yang dimiliki karyawan agar tetap tinggi dan baik dalam bekerja. Walaupun karyawan telah memiliki motivasi yang tinggi, tetapi target produksi yang ditentukan perusahaan belum tercapai. Namun adanya kenaikan pencapaian produksi dari tahun 2015 sampai tahun 2016 meskipun belum mencapai target produksi yang ditentukan. Artinya karyawan memiliki motivasi yang tinggi untuk melakukan pekerjaannya walaupun belum dapat mencapai target produksi. Hal ini mungkin dipengaruhi oleh faktor usia di mana rata-rata karyawan yang bekerja di bagian produksi ini berusia $>41$ tahun.

Pekerja yang berusia di atas 40 tahun sering mengalami kelelahan dalam bekerja. Hal ini diungkapkan oleh Budiman et al. (2016) karena menurutnya umur yang semakin meningkat juga memiliki tanggung jawab yang besar, tidak hanya di tempat kerja tetapi juga di rumah. Dalam penelitiannya mengungkapkan bahwa tenaga kerja yang berumur 40-50 tahun akan lebih cepat mengalami kelelahan dibandingkan dengan tenaga kerja yang relatif muda sehingga menyebabkan menurunnya kondisi fisik karyawan yang juga akan mempengaruhi kualitas atau kinerja kerjanya pula. Karena menurut Handoko (2001), faktor lain yang dapat mempengaruhi kinerja seorang karyawan selain motivasi kerja adalah kondisi fisik pekerja. Maka perlu diperhatikan oleh perusahaan untuk menyeimbangi usia karyawannya dan melakukan regenerasi karyawan dengan menggantikan karyawan-karyawan yang sudah pensiun dengan karyawan yang memiliki usia muda (18 - 23 tahun).

Selain itu perusahaan perlu meningkatkan motivasi karyawan dengan menyesuaikan kompensasi yang diterima oleh karyawan bahwa pekerjaan yang mereka lakukan mendapatkan kompensasi secara adil dalam perbandingan dengan pekerjaan yang sama pada perusahaan lain.

\section{SIMPULAN}

Dalam menghadapi persaingan di dunia industri ini, sebagai perusahaan tentu saja harus memiliki keunggulan dibandingkan dengan perusahaan lain yang sejenis agar mendapatkan kepercayaan dari konsumen. Untuk mewujudkan hal tersebut, perusahaan perlu memiliki kinerja karyawan yang baik. Di mana untuk meningkatkan kinerja karyawan yang baik maka perlu diperhatikan beberapa hal yang mempengaruhi baik tidaknya kinerja dari karyawan tersebut. Berdasarkan penelitian yang dilakukan terhadap salah satu perusahaan kaca di Indonesia, menunjukkan bahwa kompensasi dan beban kerja berpengaruh terhadap motivasi kerja. Kompensasi dan motivasi kerja berpengaruh terhadap kinerja karyawan. Beban kerja tidak memiliki pengaruh langsung terhadap kinerja karyawan. Motivasi kerja memiliki pengaruh terbesar bagi kinerja karyawan dibandingkan dengan kompensasi dan beban kerja. 
Hasil perhitungan menunjukkan bahwa tingkat motivasi kerja termasuk dalam kategori tinggi karena memiliki nilai MPS pada interval 44 - 125 sedangkan beban kerja mental karyawan yang bekerja termasuk kategori beban kerja mental tinggi karena memiliki nilai interval 61 80 sehingga perlu dilakukan perhitungan jumlah karyawan optimal bagi karyawan.

Penentuan variabel laten didasarkan pada kuesioner pendahuluan di mana variabel- variabel dalam kuesioner tersebut hanya didasarkan pada jurnal-jurnal penelitian terdahulu dan pendapat ahli, sehingga kurang mewakili permasalahan pada perusahaan tersebut. Maka dari itu, untuk penelitian selanjutnya dapat dilakukan wawancara agar lebih mengetahui kondisi yang menyebabkan keluhan bagi pekerja sehingga didapat variabel-variabel yang dapat mewakili permasalahan pada perusahaan terebut. Selain itu penelitian ini hanya difokuskan pada 1 divisi saja yaitu bagian produksi. Sehingga diharapkan pada penelitian selanjutnya dapat dilakukan pada 1 perusahaan agar mendapatkan hasil yang lebih akurat dan menghindari hasil yang bias.

\section{DAFTAR PUSTAKA}

Anita, J., Aziz, N., \& Yunus, M. (2019). The Effect of Placement and Work Load on Work Motivation and Its Impact on Employee Work Performance at Labor and Population Mobility Agency of Aceh Province, Indonesia. International Journal of Scientific \& Technology Research, 8(4), 225-229.

Bollen, K. A. (1989). Structural Equations with Latent Variables. John Wley \& Sons, Inc.

Brown, H. D. (2000). Principles of language learning and teaching. The Free Press.

Budiman, A., Husaini, H., \& Arifin, S. (2016). Hubungan Antara Umur dan Indeks Beban Kerja dengan Kelelahan pada Pekerja di PT. Karias Tabing Kencana. Jurnal Berkala Kesehatan, 1(2), 121-129. http://dx.doi.org/10.20527/jbk.v1i2.3151

Garbutt, D. (2010). Kas Management (A. Basalamah, Trans.). Pustaka Binaman Pressindo. (Karya Asli terbit 1985)

Ghozali, I. \& Fuad. (2005). Structural Equation Modeling. Badan Penerbit Universitas Diponogoro.

Hancock, P. \& Meshkati (1998). Human Mental Workload. North Holland.

Handoko, T. H. (2001). Manajemen Personalia dan Sumber Daya Manusia (2nd ed.). BPFE.

Hariandja, M. T. (2002). Manajemen Sumber Daya Manusia. Grasindo.

Hasibuan, M. S. P. (2000). Manajemen Sumber Daya Manusia. Bumi Aksara.

Imlawal, T. \& Winarningsih. (2016). Pengaruh Gaji dan Motivasi Kerja Terhadap Kinerja Karyawan Players Pool N Lounge. Jurnal Ilmu dan Riset Manajemen, 5(2). 
Kasmir. (2016). Manajemen Sumber Daya Manusia, Teori dan Praktik. Raja Grafindo Persada.

Kotler, P. (1997). Marketing Management "Analysis, Planning, Implementation and Control" (9th ed.). Prentice Hall International, Inc.

Munandar, A. S. (2006). Psikologi Industri dan Organisasi. UI Press.

Oktaviana, P. A. (2015). Pengaruh Beban Kerja dan Komunikasi Terhadap Motivasi Serta Dampaknya Pada Kinerja Karyawan (No. Publikasi 17091) [Skripsi Sarjana, Universitas Dian Nuswantoro Semarang]. UDiNus Repository.

Omolayo, B.O. \& Omole, O. C. (2013). Influence of mental workload on job performance. International Journal of Humanities and Social Science, 3(15), 238-246.

Paramitadewi, K. F. (2017). Pengaruh Beban Kerja dan Kompensasi Terhadap Kinerja Pegawai Sekretariat Pemerintah Daerah Kabupaten Tabanan. E-Jurnal Manajemen, 6(6), 3370-3397.

Porter, M.E. (1986). Competitive Strategy: Techniques for Analyzing Industries and Competitors. The Free Press.

Putri, U. L., \& Handayani, N. U. (2017). Analisis Beban Kerja Mental dengan Metode NASA TLX pada Departemen Logistik PT ABC. Industrial Engineering Online Journal, 6(2). 